\title{
TINKLAINĖS POKYČIAI NĖŠČIŲJŲ HIPERTENZINIŲ BŪKLIŲ METU
}

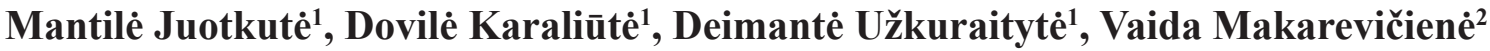 \\ ${ }^{1}$ Lietuvos sveikatos moksly universitetas, \\ ${ }^{2}$ Lietuvos sveikatos mokslu universiteto Kauno ligonine
}

Raktažodžiai: preeklampsija, eklampsija, něštumas, hipertenzinès nėščiujjų būklès, tinklainè, retinopatija, tinklainès atšoka, tinklainès ligos, akis, rega.

\section{Santrauka}

Tikslas - išsiaiškinti, kaip kinta tinklainè nėščiujų hipertenzinių būklių metu ir įvertinti dažniausiai aprašomus akių pokyčius néščiosioms. Tyrimo metodas - sisteminė literatūros apžvalga. Atrinkti straipsniai, kuriuose aprašomi tinklainès pokyčiai něščiujų hipertenzinių būklių metu. Apžvalga atlikta naudojantis elektronine duomenų baze PubMed (Medline). Rezultatai. Nèštumo metu stebimi akių būklei ịtakos turintys hormoniniai, metaboliniai, hematologiniai, kraujagysliniai ir imunologiniai pokyčiai. Akių simptomai išsivysto iki 100 proc. nėščiuju, kurioms nustatoma preeklampsija ir eklampsija. Něščiuju hipertenzinių būklių sukelti akies pokyčiai dažniausiai pasireiškia suprastejusia rega, susiliejančiu vaizdu, fotopsija, regos lauko iškritimu. Autoriai nurodo, kad būklès gali tęstis iki metų po gimdymo, tačiau dauguma akių pokyčių praeina savaime ir rega visiškai atsikuria. Pasitaiko ir vèlyvujų komplikacijų, kurios gali išlikti visą gyvenimą. Literatūroje dažniausiai aprašomos būklès yra hipertenzinè retinopatija, tinklainès atšoka, tinklainės kraujagyslių okliuzija bei progresuojanti diabetiné retinopatija. Siekiant įvertinti akių pokyčius hipertenzinès nèštumo būklès metu, atliekami įvairūs tyrimai. Dažniausias tyrimas - oftalmoskopija. Itin svarbus progresuojančių būklių stebėjimas ir savalaikis gydymas. Išvados. Hipertenzinès něščiujų būklès dažnai sukelia arba provokuoja reikšmingus akių pokyčius, dauguma jų yra grižtami ir intervencijos nereikalingos. Itin svarbi savalaikè ūmių ir progresuojančių būklių diagnostika bei gydymas, saugus nėščiajai ir vaisiui.

\section{Ivadas}

Nèštumo metu stebimi viso organizmo pokyčiai. Poveikis akiai něštumo metu gali būti tiek fiziologinio, tiek patologinio pobūdžio ir gali pasireikšti kaip nauja akies patologija arba jau buvusių būkliu pokyčiai [1-5]. Dauguma naujai atsiradusių pokyčiu yra nekenksmingi, tačiau buvusios būklès gali pablogèti iki 55 proc. néščiujų $[1,6]$. Dažniausiai po nèštumo nutrūkus šiems procesams, akių pokyčiai praeina savaime, tačiau kai kuriais atvejais jie gali išlikti ir turèti ilgalaikių pasekmių gimdyvès sveikatai $[4,5,7]$.

Hipertenzinès būklès turi didelę svarbą nėščiosios sveikatai ne tik něštumo, bet ir gimdymo bei ankstyvuoju pogimdyviniu laikotarpiu [3]. Autorių duomenimis, šios patologijos išsivysto apie 5 proc. (duomenys svyruoja tarp 2-14\%) visų gimdyvių ir sukelia didelį gimdyvių ir perinatalinị mirštamumą $[1,3,8]$. PSO nurodo, kad 3-8 proc. nëščujų visame pasaulyje išsivysto ne tik preeklampsija ar eklampsija, tačiau ir tokios būklès, kaip lètinè ar gestacinè hipertenzija.

Tinklainès būklè nèštumo metu yra itin aktuali tema. Esant hipertenzinei būklei, akių simptomai išsivysto iki 80 proc. (kai kurių autorių duomenimis, net iki 100\%) néščiujų $[6,8,9]$. Manoma, kad tinklainès pokyčiai nèštumo metu netiesiogiai parodo placentos vaskuliarizacijos būklę, o kartu ir placentos nepakankamumą [10].

Tyrimo tikslas - išsiaiškinti, kaip kinta tinklaine něščiujų hipertenzinių būklių metu ir ịvertinti dažniausiai aprašomus akių pokyčius nèščiosioms.

\section{Tyrimo medžiaga ir metodai}

Tyrimo metodas - sisteminè literatūros apžvalga. Atrinkti straipsniai, kuriuose aprašomi tinklainès pokyčiai nėščiujjų hipertenzinių būklių metu. Apžvalga atlikta naudojantis elektronine duomenų baze PubMed (Medline). Tyrimui gautas LSMU bioetikos centro pritarimas (Nr. BEC-MF-105).

\section{Tyrimo rezultatai}

Preeklampsija, eklampsija ir tinklainė. Hipertenzinès nëščiujjų būklès paveikia visą organizmą - kardiovaskulinę, hematologinę, inkstų ir kepenų funkcijas, galimos ir neurologinès išraiškos. Preeklampsijos ir eklampsijos metu išsivystę pokyčiai gali paveikti regos kelią nuo priekinių segmentų iki galvos smegenų žievès, atsakingos už regą [10]. Sergančiųu ų preeklampsija ir eklampsija regos sistema paveikiama ir 
simptomai pasireiškia maždaug 25-50 proc. (kai kurių autorių duomenimis - 30-80 \%) pacienčių [6-9].

Nèščiųų hipertenzinių būklių sukelti akies pokyčiai dažniausiai pasireiškia suprastejusia rega, susiliejančiu vaizdu, fotopsija, regos lauko iškritimu. Preeklampsija ir eklampsija gali sukelti hipertenzinę retinopatiją, eksudacinę tinklainès atšoką arba žievinès kilmès aklumą [5]. Nors esant hipertenzinėms nėščiujjų būklėms regos sutrikimai ganètinai dažni, visiškas aklumas sąlyginai retas - pasireiškia 1-3 proc. pacienčių [10]. Neurooftalmologiniai sutrikimai, tokie, kaip veninių ančių trombozè, gerybinè intrakranijinè hipertenzija, hipofizès adenoma, meningioma ir optinis neuritas turètų būti itin akylai stebimi ir diferencijuojami dèl ūmaus regos netekimo rizikos, didejjančio intraokulinio spaudimo bei okulomotorinio paralyžiaus [3,11-13]. Ūmiu regos netekimu pasireiškia ir retai su hipertenzine něščiosios būkle siejama patologija - tinklainès hemoragija $[11,13]$. Rega gali būti prarasta negrižtamai, kai diagnozuojama panaši ị Purtscher (angl. Purtscher-like) retinopatija. Ši būklè, manoma, atsiranda dèl tinklainès arterijų embolizacijos vaisiaus vandenimis [13]. Preeklampsijos metu literatūroje daugiausia aprašomos ir charakterizuojamos būklès bei jų patofiziologiniai mechanizmai yra hipertenzinè retinopatija, tinklainès atšoka, tinklainès kraujagyslių okliuzija bei progresuojanti diabetinè retinopatija $[1,4,6,8-10,13,14]$.

Hipertenzinė retinopatija yra vienas dažniausių akių pokyčių, atsirandančių esant preeklampsijai ir eklampsijai. Ji pasireiškia maždaug 60-70 proc. nèščiujjų, sergančių preeklampsija $[10,13]$. Patofiziologiniame lygyje pirminis tinklainès atsakas ị padidejjusi spaudimą - kraujagyslių spazmas. Hipertenzinès retinopatijos laipsnis dažniausiai koreliuoja su preeklampsijos sunkumu $[9,11]$. Atrasta reikšminga sąsaja tarp sulètejusios kraujotakos ir preeklampsijos parodo, kad tinklainès kraujagyslių spazmas ir rezistentiškumas galètų būti tinkamas paaiškinimas regos sutrikimų atsiradimui, esant hipertenzinèms néščiujų būklèms [10].

Tinklainès atšoka - tai ganètinai reta (iki 1-3\% preeklampsija ir iki 5-10\% eklampsija sergančių pacienčių) patologija, apibūdinama kaip neurosensorinès tinklainès dalies atsisluoksniavimas nuo pigmentinio tinklainès epitelio ir yra viena iš skubių oftalmologinių būklių [13]. Tikslus patofiziologinis tinklainès atšokos mechanizmas nèra aiškus, tačiau ši patologija dažniausiai pasireiškia esant sunkiai preeklampsijai arba eklampsijai. Kliniškai tinklainès atšoka pasireiškia staigiu, neretai abipusiu regos netekimu $[10,13]$. Ši būklè dažniausiai išsivysto gimdymo metu, arba iškart po jo. Pacientėms sunki preeklampsija gali sukelti negrịžtamą regos netekimą dèl pigmentinio tinklainès epitelio nekrozès [14].

Tinklainès kraujagyslių okliuzija dažniausiai pasireiškia ankstyvuoju pogimdyviniu laikotarpiu, tačiau gali manifestuoti tiek nèštumo, tiek gimdymo metu, o jos rizikos veiksniai yra sąlyginai tie patys, kaip ir preeklampsijos [13]. Ši patologija gali būti sukelta diseminuotos intravaskulinès koaguliacijos (DIK) sindromo, tinklainès venų okliuzijos dèl HELLP sindromo ir tinklainès arterijos kraujagyslès dèl koaguliacinès sistemos suaktyvejjimo [9]. Dèl aukšto kraujospūdžio sutrikus normaliai kraujo apytakai, prasideda tinklainès edema, kraujavimas, patologinès kraujotakos formavimasis, sukeliantis dalinį arba visišką regos netekimą [13].

Nèštumas ir padidejjęs kraujospūdis gali provokuoti jau esančią diabetinę retinopatiją, kadangi aukštas kraujospūdis néštumo metu yra svarbus šios ligos progresavimo rizikos veiksnys $[6,9]$. Diabetu sergančios moterys turètų būti tiriamos gydytojo oftalmologo prieš nèštumą ir jo metu, o ypač akylai stebimos sergančios diabetu, esant preeklampsijos išsivystymo rizikai. Néččiosiosios, sergančios 1 tipo cukriniu diabetu, kurioms iki nèštumo pradžios nebuvo nustatyti akių dugno pokyčiai (arba šie pokyčiai buvo minimalūs), turès mažesnị polinkị diabetinès retinopatijos progresavimui, nei néščiosios, kurioms šie pokyčiai jau buvo iki néštumo [6].

Galimos ir vèlyvos, sunkiau pastebimos komplikacijos, kurios pacientems, sirgusioms preeklampsija, gali išlikti visą gyvenimą [10]. Tokie pokyčiai apima negrižtamą arteriolių spindžio susiaurejjimą, tinklainès pigmentinio sluoksnio epiteliopatiją, proliferacinę retinopatiją ir gyslainès atrofiją $[10,13]$.

Diagnostikos ypatumai. Dažniausiai oftalmologų praktikoje naudojamas tyrimas - oftalmoskopija gali lengvai nustatyti tinklainès arteriolių pokyčius, kraujavimą, eksudatą, disko pokyčius ar tinklainès atšoką [15]. Preeklampsijos metu maždaug 50-100 proc. moterų oftalmoskopu stebimi ankstyvieji pokyčiai - arteriolių spazmas, kuri patvirtina segmentinis arba generalizuotas tinklainès arteriolių susitraukimas ir kraujagyslinio dangalo suplonejjimas. Gali būti ir kitų specifinių požymių - hemoragijos, Elschnig dėmès, edema ir „vatos“ minkštieji eksudatai (angl. cotton wool spots) $[9,11,13,16-18]$. Keith-Wagener-Barker klasifikacijoje akies dugno pokyčiai suskirstyti ị stadijas: 1 stadija apima minimalius tinklainès arteriolių susiaurèjimus; 2 stadijoje matomas didelis arteriolių susiaurèjimas ir sklerozé; 3 stadijoje stebimi prieš tai minèti pokyčiai ir tinklainès edema, kraujosruvos, eksudatai; 4 stadijoje randama optinio disko edema. Tyrimų metu pastebėta, jog esant bet kurios stadijos retinopatijai, sistolinis ir diastolinis kraujospūdžiai buvo žymiai padidèję, tad nustačius sunkią preeklampsiją, reikia tikrinti, ar nėra retinopatijos požymių akies dugne bei skirti tinkamą gydymą [17].

Atliekant akių diagnostinius tyrimus, dažnai reikalingi vaistai. Diagnostikoje vartojami midriatikai atropinas, epinefrinas, tropikamidas ir kt. yra saugūs vienkartiniam nau- 
dojimui, tačiau kartotinis vartojimas kontraindikuotinas dèl teratogeninio poveikio [10]. Apie fluoresceino teratogenini poveikị nèra žinoma, tačiau jis pereina placentą ir gali sukelti riziką vaisiui, ypač pirmą nėštumo trimestrą [12].

Fluoresceino angiografiniai tyrimai, nors ir riboti dèl saugumo aspektų, naudingi aiškinantis tinklainès ir gyslainès kraujagyslių pokyčius. Be tinklainès atšokos, fluoresceino angiografijos metu matoma tinklainès kraujagysliu dekompensacija $[15,19]$. Pastebèta, jog tinklainès atšoka preeklampsijos metu yra antrinè dèl gyslainès arteriolių ir kapiliarų okliuzijos. Angiogramose matoma gyslainès kraujagyslių išemija ir vèluojantis choriokapiliarų užsipildymas fluoresceinu [20].

Vis plačiau naudojamas greitas, neinvazinis ir netoksiškas optinès koherentinès tomografijos tyrimas (OKT) yra naudingas gauti didelès skiriamosios gebos tinklainès ir pigmentinio epitelio vaizdus realiu laiku [21]. Tai nekontaktinis, biomikroskopinis prietaisas, paremtas mažo koherentiškumo interferometrija. Nëščiosioms, kurių anamnezejje nestabilus kraujospūdis ar hipertenzija, reguliarus OKT atlikimas yra svarbus nustatyti dugno pokyčius ir laiku imtis reikiamų priemonių [22]. Spektrinė OKT yra aukštos raiškos tinklainės mikrostruktūros vaizdavimo technologija, galinti išmatuoti kraujotaką preeklampsinių būklių metu. Šis tyrimas ypač tinkamas diagnozuoti su priekiniais ir užpakaliniais akiduobės segmentais susijusias ligas, pirminę ar antrinę tinklainès atšoką preeklampsijos metu bei esant nedideliam akies terpès drumstumui [15]. Tinklainès atšoka ir kiti morfologiniai pokyčiai gerai matomi OKT vaizduose [22-24].

Ultrasonografija ir tinklainès kraujagyslių doplerinis tyrimas lengvai atliekamas ir ekonomiškas. Ultragarso vaizduose galima įvertinti akių pokyčius ir diagnozuoti serozinę tinklainès atšoką, net kai tyrimą sunkina ragenos drumstumas, katarakta ar kraujavimas. Doplerinio tyrimo metu nustato-

1 lentelè. Hipertenzinių būklių nèštumo metu sukeltų akių ligų gydymas

Sudaryta autoriu pagal 6,9-12,16-19,25,26.

\begin{tabular}{|l|l|}
\hline Liga & \multicolumn{1}{|c|}{ Gydymas } \\
\hline $\begin{array}{l}\text { Hipertenzinė retinopatija su ar } \\
\text { be preeklamsijos; eklampsijos }\end{array}$ & $\begin{array}{l}\text { Vaistai, atidus stebejimas lengvos } \\
\text { preeklampsijos atveju, gimdymas } \\
\text { esant sunkiai preeklampsijai ir } \\
\text { eklampsijai }\end{array}$ \\
\hline $\begin{array}{l}\text { Centrinė serozinė chorioreti- } \\
\text { nopatija }\end{array}$ & Stebėjimas \\
\hline Diabetinè retinopatija & $\begin{array}{l}\text { Fotokoaguliacija, anti - KEAF } \\
\text { injekcija ị stiklakūni, vitrektomija }\end{array}$ \\
\hline $\begin{array}{l}\text { Tinklainės kraujagyslių okliu- } \\
\text { zija }\end{array}$ & Stebejjimas \\
\hline $\begin{array}{l}\text { Tinklainės plyšimas su ar be } \\
\text { atšokos }\end{array}$ & $\begin{array}{l}\text { Gydymas lazeriu, sklerozantais } \\
\text { arba vitrektomija }\end{array}$ \\
\hline
\end{tabular}

mas pulsacijos indeksas (PI) padeda ịvertinti kraujotakos pokyčius [15].

Gydymo ypatumai. Sveikatos priežiūros specialistams reikia patikrinti moterị nėštumo pradžioje dẻl aukšto kraujospūdžio ir hipertenzijos keliamos rizikos. Jei reikia, naudoti greitai veikiančius antihipertenzinius vaistus ir planuoti gimdymą [8]. Yra žinoma ankstyvos diagnozès ir tinkamo šios sunkios néštumo komplikacijos gydymo svarba, siekiant išvengti bet kokios tikètinos negrįžtamos žalos [1]. Patologinių akių pokyčių atskyrimas nuo fiziologinių yra svarbus individualizuotam gydymui ir prevencijai, bet visada reikia pasverti gydymo naudą ir galimą žalą tiek motinai, tiek vaisiui $[6,10]$. Akių pokyčių laipsnị veikia něščiųjų sveikatos būklè, pvz., diabetas, inkstų liga ar hipertenzija nëštumo metu $[6,9,24]$.

Žinoma, kad retinopatijos laipsnis teigiamai koreliuoja su preeklampsijos sunkumu ir eklampsija [6,9]. Vienintelis galutinis, patvirtintas preeklampsijos ir eklampsijos gydymas yra gimdymas. Prieštraukuliniai vaistai (pvz., magnio sulfatas) ir antihipertenzinis gydymas (pvz., nifedipinu ar labetololiu) taip pat gali būti naudingi, gydant šias pacientes [6]. Nors akių komplikacijos ir dažnos néštumo metu, daugelis jų yra lengvos, reikalauja tik stebejjimo arba nesudètingo gydymo [10] (1 lentelè).

Hipertenzijos sukelti akies pakitimai daugeliu atvejų yra grižtami, nes kraujospūdis po gimdymo normalizuojasi, nors tinklainès suplonejjimo ir (arba) atrofijos židiniai gali išlikti $[6,9,13]$. Pacientèms, sergančioms lengvos stadijos retinopatija, akių simptomai visiškai išnyko per 3 mėnesius po gimdymo, o sergančioms vidutinès-sunkios stadijos retinopatija - per 1 metus po gimdymo [17]. Svarbu prisiminti, kad galima rimta oftalmologinè patologija, kurią reikia gydyti nedelsiant [10]. Pavyzdžiui, diabetinè retinopatija gali paūmèti ir greitai komplikuotis stiklakūnio kraujavimu, todèl reikia atlikti fotokoaguliaciją lazeriu, nustačius diagnozę [6,12,24-26]. Sergančiujų diabetine retinopatija gydymas lazeriu prieš něštumą, gali sumažinti susirgimo progresavimo riziką iki 50 procentu $[6,25]$. Dauguma tinklainès atšokos atvejų po gimdymo gali išnykti savaime, bet gali prireikti

2 lentelè. Diabetinès retinopatijos patikros programa Sudaryta autoriu pagal 6,13,16, 23-27.

\begin{tabular}{|l|l|}
\hline $\begin{array}{l}\text { Visos diabetu sergančios } \\
\text { pacientės }\end{array}$ & Pirmaji néštumo trimestrą \\
\hline $\begin{array}{l}\text { Nėra diabetinės retinopatijos } \\
\text { arba lengva }\end{array}$ & $\begin{array}{l}\text { Trečiaji néštumo trimestrą, vė- } \\
\text { liau kas 3-12 mén. }\end{array}$ \\
\hline $\begin{array}{l}\text { Vidutinio laipsnio diabetinė re-- } \\
\text { tinopatija }\end{array}$ & $\begin{array}{l}\text { Kiekvieną trimestrą, vėliau kas } \\
\text { 3-12 mèn. }\end{array}$ \\
\hline $\begin{array}{l}\text { Sunkaus laipsnio diabetinė re-- } \\
\text { tinopatija }\end{array}$ & $\begin{array}{l}\text { Kiekvieną trimestrą, vėliau kas } \\
1-3 \text { mèn. }\end{array}$ \\
\hline
\end{tabular}


gydymo lazeriu ar kitomis priemonėmis nėštumo metu ar po jo $[6,9,13]$.

Dažniausiai stengiamasi išvengti ar atidèti vaistų vartojimą nèštumo metu, bet kai kuriais atvejais tai neįmanoma. Svarbu, kad gydytojai būtų gerai informuoti apie galimą vaistų teratogeninị poveikị [9]. Ilgalaikių duomenų apie oftalmologinius vaistus nèštumo ir žindymo laikotarpiu nepakanka, todèl gydytojai turètų pasikonsultuoti su ekspertais prieš skirdami bet kokị gydymą pacientei $[10,16]$. Sisteminę akių lašų rezorbciją gali sumažinti mažiausios įmanomos vaisto dozès skyrimas, o vietoje sisteminio gydymo vaistais, laikinai gali būti naudojamos vietinès priemonès $[9,10]$. Nors antivaskulinio endotelio augimo faktoriaus (anti-KEAF) preparatai būtu tinkami tam tikrų akių patologijų gydymui, tačiau patartina, kad šie preparatai būtų skiriami tik remiantis patikimomis klinikinemis indikacijomis ir kuo vèlesniu něštumo metu, nes teoriškai jie gali paveikti placentos vaskuliarizaciją $[6,9,13,16,19,25]$. Nėštumo metu reikètų vengti operacijų, o kai tai yra neišvengiama, rekomenduojama dalyvauti akušerinei komandai ir, jei įmanoma, naudoti vietinę anesteziją $[9,13,16]$.

Priežiūra. Po néščiosioms pasireiškusių hipertenzinių būklių rekomenduojamas tolesnis stebejjimas dẻl ilgalaikių oftalmologinių komplikacijų [18]. Diabetinè retinopatija ir tinklainès atšoka buvo reikšmingai susijusi su preeklampsijos, eklampsijos istorija, o akių dugno pokyčiai parodo hipertenzinès būklès sunkumą ir galima ịtarti nepageidaujamus néštumo rezultatus $[4,17,18]$. Moterims, planuojančioms pastoti ir sergančioms predisponuojančiomis ligomis, tokiomis kaip diabetas, oftalmologai rekomenduoja prieš nèštumą išsitirti akių dugną (2 lentelè).

Tyrimo, kurio metu moterys turèjo tinklainès degeneraciją ar atšoką, nebuvo pastebèta koreliacijos tarp natūralaus gimdymo ir naujos tinklainès atšokos atsiradimo, todèl vien tik ankstesnè akių liga neturètų būti Cezario pjūvio indikacija [16]. Akių dugno radiniai dažniausiai pasitaikè pirmakartei $(55,80 \%)$ ir antrakartei $(50,79 \%)$, o antras pikas buvo pastebètas nuo šešto něštumo (83, 33\%) [25].

Kiti nèštumai, tolimesnė eiga. Yra duomenų, kad pasikartojančios preeklampsijos rizika vélesnio néštumo metu svyruoja nuo 11,5 iki 65 proc., tačiau rasta daug ịrodymų, kad preeklampsijos kartojimasis didina širdies ir kraujagyslių ligų bei medžiagų apykaitos sutrikimų riziką [8]. Preeklampsijos sukelti tinklainès kraujagyslių pokyčiai, išliekantys vienerius metus po gimdymo, gali būti matomi ir praejjus šešeriems metams. Tai gali atspindèti ilgalaikę mikrovaskulinę disfunkciją kitose organų sistemose [2,11]. Pacienčių, sergančių sunkia retinopatija dèl sunkios hipertenzinès būklès, perinataliniai rezultatai dažniau buvo prasti $[10,16,17]$. Preeklampsija sirgusios moterys turi būti infor- muotos apie galimas ilgalaikes komplikacijas, kuriu išvengti gali padèti fizinis krūvis ir sveikas gyvenimo būdas [8]. Sunkios diabetinès retinopatijos atveju kontraindikuotinas didelio intensyvumo fizinis aktyvumas, nes gali padidinti komplikacijų riziką [10].

\section{Išvados}

1. Hipertenzinès nėščiųjų būklès dažnai sukelia arba provokuoja reikšmingus akių pokyčius, dauguma jų yra grižtami ir nereikalingos klinikinès intervencijos.

2. Dažniausiai autorių aprašomos ir klinikinëje praktikoje pasitaikančios tinklainès patologijos, esant hipertenzinei něšciosios būklei: hipertenzinè retinopatija, tinklainès atšoka, tinklainès kraujagyslių okliuzija, diabetinès retinopatijos progresavimas.

3. Akių pažeidimai, sukelti nėščiosios hipertenzinès būklès, turètų būti diagnozuojami neinvaziniais tyrimo būdais, tokiais kaip oftalmoskopija, OKT, ultrasonografija ar doplerinis tinklainès kraujagyslių tyrimas. Itin svarbu riboti invazinius tyrimus.

4. Akių pokyčiai nėštumo metu esant hipertenzinei nèščiosios būklei, turi būti nuolat stebimi, o išsivysčius ūmioms akių būklèms reikalingas skubus ir tikslingas gydymas, siekiant išvengti ilgalaikès negrị̌tamos žalos.

5. Akių ligų gydymą nëštumo metu sunkina galimas šalutinis oftalmologinių vaistų poveikis vaisiaus raidai.

\section{Literatūra}

1. Arab M, Entezari M, Ghamary H, et al. Peripapillary retinal nerve fiber layer thickness in preeclampsia and eclampsia. Int Ophthalmol 2018;38:2289-2294.

https://doi.org/10.1007/s10792-017-0718-9

2. Benschop L, Schalekamp-Timmermans S, Roeters van Lennep JE, Jaddoe VWV, Wong TY, Cheung CY, Steegers EAP, Ikram MK. Gestational hypertensive disorders and retinal microvasculature: the generation R study. BMC Med 2017;15(1):153. https://doi.org/10.1186/s12916-017-0917-2

3. Kirollos S, Skilton M, Patel S, Arnott C. A systematic review of vascular structure and function in pre-eclampsia: non-invasive assessment and mechanistic links. Front Cardiovasc Med 2019;6:166.

https://doi.org/10.3389/fcvm.2019.00166

4. Beharier O, Davidson E, Sergienko R, Szaingurten-Solodkin I, Kessous R, Charach R, Belfair NJ, Sheiner E. Preeclampsia and future risk for maternal ophthalmic complications. American Journal of Perinatology 2016; 33(07):703-707. https://doi.org/10.1055/s-0036-1571321

5. Shah AP, Lune AA, Magdum RM, Deshpande H, Shah AP, Bhavsar D. Retinal changes in pregnancy-induced hypertension. Med J DY Patil Univ 2015;8:304-7. https://doi.org/10.4103/0975-2870.157067 
6. Naderan M. Ocular changes during pregnancy. Journal of Current Ophthalmology 2018;30930:202-210.

https://doi.org/10.1016/j.joco.2017.11.012

7. Xiong T, Mu Y, Liang J, Zhu J, Li X, Li J, Liu Z, Qu Y, Wang $\mathrm{Y}, \mathrm{Mu} \mathrm{D}$. Hypertensive disorders in pregnancy and stillbirth rates: a facility-based study in China. Bull World Health Organ 2018;96:531-539.

https://doi.org/10.2471/BLT.18.208447

8. Adekomi AD, Moodley J, Naicker T. Neuropathological complications associated with hypertensive disorders of pregnancy. Hypertens Pregnancy 2019;38(3):171-175. https://doi.org/10.1080/10641955.2019.1626417

9. Yenerel NM, Küçümen RB. Pregnancy and the Eye. Turk J Ophthalmol 2015;45(5):213-219.

https://doi.org/10.4274/tjo.43815

10. Rezai S, LoBue S, LoBue TD, Giovane R, Carney MD, Henderson CE. Ophthalmic complications and ocular changes in pregnancy- a review. Obstet Gynecol Int J 2016;4(1):00093. https://doi.org/10.15406/ogij.2016.04.00093

11. Soma-Pillay P, Pillay R, Wong TY, Makin JD, Pattinson RC. The effect of pre-eclampsia on retinal microvascular caliber at delivery and post-partum. Obstet Med 2018;11(3):116-120. https://doi.org/10.1177/1753495X17745727

12. Park YJ, Park KH, Woo SJ. Clinical features of pregnancyassociated retinal and choroidal diseases causing acute visual disturbance. Korean J Ophthalmol 2017;31(4):320-327. https://doi.org/10.3341/kjo.2016.0080

13. Rosenthal JM, Johnson MW. Management of retinal diseases in pregnant patients. J Ophthalmic Vis Res 2018;13(1):62-65. https://doi.org/10.4103/jovr.jovr_195_17

14. Duru N, Ulusoy DM, Özköse A, Ataş M, Karatepe AS, Ataş F, Arifoğlu HB, Yılmaz U. Choroidal changes in pre-eclampsia during pregnancy and the postpartum period: comparison with healthy pregnancy. Arq Bras Oftalmol 2016;79(3):143-146. https://doi.org/10.5935/0004-2749.20160044

15. Bakhda RN. Specialized diagnostic investigations to assess ocular status in hypertensive diseases of pregnancy. Diseases 2016;4:19.

https://doi.org/10.3390/diseases4020019

16. Kalogeropoulos D, Sung VCT, Paschopoulos M, Moschos MM, Panidis P, Kalogeropoulos C. The physiologic and pathologic effects of pregnancy on the human visual system. Journal of Obstetrics and Gynaecology 2019;39(8):1037-1048. https://doi.org/10.1080/01443615.2019.1584891

17. Ye L, Shi M, Zhang Y, Zhang J, Zhu C, Zhou R. Risk factors and pregnancy outcomes associated with retinopathy in patients presenting with severe preeclampsia. Medicine 2020;99(11): e19349. https://doi.org/10.1097/MD.0000000000019349

18. Abdellaoui T, Bouayad G, Elkhoyaali A, Laaribi N, Mouzari Y, Elasri F, Reda K, Oubaaz A. Bilateral serous retinal detachment complicating preeclampsia. Indian J Med Spec 2017;9(1):36-39. https://doi.org/10.1016/j.injms.2017.11.004

19. Naderan M, Sabzevary M, Rezaii K, Banafshehafshan A, Hantoushzadeh S. Intravitreal anti-vascular endothelial growth factor medications during pregnancy: current perspective. Int Ophthalmol 2020;1-9. https://doi.org/10.1007/s10792-020-01610-2

20. Kim JW, Park MH, Kim YJ, Kim YT. Comparison of subfoveal choroidal thickness in healthy pregnancy and pre-eclampsia. Eye (Lond) 2016;30(3):349-354. https://doi.org/10.1038/eye.2015.215

21. Zhang J, Wang H, Yu Q, Tong Q, Lu Q. Enhanced depth imaging optical coherence tomography: a new way measuring choroidal thickness in pregnant women. Journal of Ophthalmology 2017; 2017:8296574.

https://doi.org/10.1155/2017/8296574

22. Wang Z, Zou Y, Li W, Wang X, Zhang M, Wang W. Application of optical coherence tomography and contrast sensitivity test for observing fundus changes of patients with pregnancy-induced hypertension syndrome. Medicine (Baltimore) 2015;94(44):e1641.

https://doi.org/10.1097/MD.0000000000001641

23. Inan S, Polat O, Cetinkaya E, Inan UU. Bilateral serous retinal detachment accompanied by a rare intraretinal fluid configuration in preeclampsia and PRES syndrome. Romanian Journal of Ophthalmology 2019; 63(1):86.

https://doi.org/10.22336/rjo.2019.13

24. Zhang Z, Lu J, Qin X. Case Report: optical coherence tomography can find typical features in pregnancy-induced hypertension with retinopathy. Optom Vis Sci 2019; 96(5):372-375. https://doi.org/10.1097/OPX.0000000000001369

25. Bakhda RN. Clinical study of fundus findings in pregnancy induced hypertension. J Family Med Prim Care 2016;5(2):424429.

https://doi.org/10.4103/2249-4863.192364

26. Morya AK, Gogia S, Gupta A, Prakash S, Solanki K, Naidu AD. Motherhood: what every ophthalmologist needs to know. Indian J Ophthalmol 2020;68(8):1526-1532.

https://doi.org/10.4103/ijo.IJO_2033_19

\section{RETINAL CHANGES IN PREGNANT WOMEN WITH HYPERTENSIVE DISORDERS}

\section{Juotkutė, D. Karaliūtė, D. Užkuraitytė, V. Makarevičienė}

Keywords: preeclampsia, eclampsia, pregnancy, hypertensive disorders of pregnancy, retina, retinopathy, retinal detachment, retinal diseases, eye, vision

Summary

Background. The goal of the overview is to elucidate the changes of the retina in pregnant women with hypertensive disorders and to evaluate the most commonly described ocular changes.

Methods. This is a systemic literature overview of articles on 


\section{4}

the retinal changes in women with hypertensive disorders. The research was conducted via the free full-text archive PubMed (Medline). Permission for the study obtained from Lithuanian University of Health Science Bioethics center no. BEC - MF - 105.

Results. During pregnancy many hormonal, metabolic, hematological, vascular and immunological changes develop that have influence on the eye's condition. Ocular symptoms occur in up to $100 \%$ of pregnant women with preeclampsia or eclampsia. The most common ocular symptoms for pregnant women with hypertensive disorders are visual impairment, blurred vision, photopsia and loss of visual field. Authors indicate that some of the ocular changes can last up to a year after giving birth, though most of the ocular changes pass spontaneously with the complete recovery of the vision. However, late complications can occur and persist later in life after preeclampsia. Most commonly in the literature are described these conditions - hypertensive retinopathy, retinal de- tachment, retinal vascular occlusion and progressive diabetic retinopathy. In order to evaluate the ocular changes in pregnancy, various diagnostic tests are used and the most common test is ophthalmoscopy. It is extremely important to follow occurring and progressive conditions and treat them well-timed.

Conclusions. Hypertensive disorders during pregnancy often cause or provoke significant ocular changes, most of them are reversible and do not require any interventions. Well-timed diagnostics and treatment of severe and progressive ocular conditions are of critical importance and they have to be safe for the mother and the fetus.

Correspondence to: deimante.uzkuraityte@gmail.com

Gauta 2020-11-23 